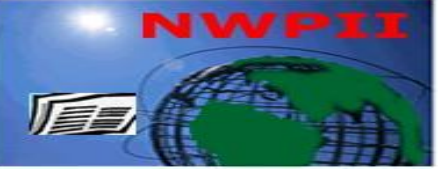

American Journal of Biomedical Sciences

ISSN: 1937-9080

nwpii.com/ajbms

\title{
Peroxynitrite-modified H3 Histone is Highly Immunogenic and Binds Circulating SLE Autoantibodies Better than Native DNA
}

\author{
M. Asad Khan ${ }^{1}$, Kiran Dixit ${ }^{1}$, Zarina Arif ${ }^{2}$, Moinuddin $^{1}$, Jalaluddin M. Ashraf $^{1}$ and \\ Khursheed Alam, ${ }^{1, *}$
}

\author{
${ }^{1}$ Department of Biochemistry, Faculty of Medicine, Aligarh Muslim University, Aligarh, India \\ ${ }^{2}$ Rajiv Gandhi Centre for Diabetes and Endocrinology, Faculty of Medicine, Aligarh Muslim University, Aligarh, India \\ Corresponding author: \\ Professor Khursheed Alam, Ph.D. \\ Department of Biochemistry \\ Faculty of Medicine \\ Aligarh Muslim University \\ Aligarh 202 002, India \\ Fax: +91-571-2720030 \\ Email: kalam786@rediffmail.com
}

Received:7 September 2012; | Revised:20 December 2012; | Accepted: 30 December 2012

\begin{abstract}
Peroxynitrite is a bifaceted reactive species. It can oxidize and nitrate proteins/nucleic acids/lipids and is involved in inflammation, apoptosis, cytotoxicity and autoimmune disorders of unknown etiology, including SLE. In this study, H3 histone exposed to peroxynitrite caused loss of tertiary structure, nitration of tyrosine residues and dityrosine formation. Experimentally produced antibodies against peroxynitrite-modified H3 histone showed specificity for the immunogen. However, cross-reactions with other nitrated proteins were also observed. We further investigated the binding of SLE autoantibodies with native DNA, native H3 histone and peroxynitrite-modified $\mathrm{H} 3$ histone to explore the possible role of modified-H3 histone in the initiation and/or progression of SLE in a sub-group of patients. The results showed preferential binding of SLE anti-nDNA autoantibodies to peroxynitrite-modified H3 histone. The visual detection of immune complex formation with native and peroxynitrite-modified $\mathrm{H} 3$ histone reiterated preferential binding of SLE autoantibodies with modified H3 histone. It may be concluded that anti-histone autoantibodies seen in a subgroup of SLE patients might be due to the immunogenicity of peroxynitrite-modified $\mathrm{H} 3$ histone.
\end{abstract}

Keywords: Peroxynitrite, nitrotyrosine, SLE, H3 histone.

\section{Introduction}

Peroxynitrite is formed by rapid reaction of nitric oxide (NO) and superoxide anion [1]. It is a potent oxidant and nitrating species and can modify a variety of biomolecules, but possesses high affinity for tyrosine residues in proteins. Moreover, 3-nitrotyrosine is a relatively specific marker of peroxynitrite mediated damage to proteins [2]. The generation of peroxynitrite by 
activated macrophages, neutrophils and endothelial cells and presence of nitrotyrosine in human tissues and fluids and in animal models of various diseases, calls for a comprehensive study of protein-peroxynitrite interactions.

Histones are conserved proteins. They play a critical role in the proper packaging of DNA within the eukaryotic nucleus and are poor immunogens. However, histones were found to be immunogenic after acetylation [3] or binding with RNA [4]. A variety of post-translationally modified (including nitrated) proteins have been shown to accumulate in apoptotic or inflamed tissues [5]. The accumulation in inflamed tissue of nitrotyrosine-containing autologous proteins, that appear as foreign to the immune system, might induce an autoimmune response and sustain a chronic inflammatory response [6]. Elevated levels of anti-nitrotyrosine antibodies have been found in synovial fluids of patients with rheumatoid arthritis and osteoarthritis [7] as well as in the sera of SLE patients $[7,8]$.

SLE is an autoimmune disease characterised by autoantibodies against nuclear antigens for which the nucleosome is considered a major autoantigen [9]. The nucleosome is comprised of an octamer of two copies each of $\mathrm{H} 2 \mathrm{~A}, \mathrm{H} 2 \mathrm{~B}, \mathrm{H} 3$ and $\mathrm{H} 4$ histones and a $146 \mathrm{bp}$ DNA. The linker histone $\mathrm{H} 1$ is highly susceptible to modifications and might be central in autoimmunity. In SLE, the nucleosomes are released from apoptotic cells and not cleared completely $[10,11]$. This results in accumulation of DNA, histones and nucleosomes in the circulation and tissues [12].

Anti-histone antibodies (AHA) are part of the so-called antinuclear antibodies family. Certain AHA subsets recognize individual histones, whereas others preferentially react with histone complexes, associated with or without DNA [13]. In contrast to anti-nucleosome antibodies that are almost exclusively found in SLE, AHA are found in several systemic and organ-specific autoimmune diseases, including SLE, as well as in infectious and neurologic diseases. Therefore, identification of in vivo targets of protein tyrosine nitration may help in understanding the development and progression of SLE. Elevated levels of peroxynitrite in SLE patients have been reported $[14,15]$.

In the present study, commercially available $\mathrm{H} 3$ histone was modified with varying concentrations of peroxynitrite. Immunogenicity of native and peroxynitrite-modified H3 histone was checked in rabbits and the binding specificity of the induced antibodies was assessed by inhibition ELISA. SLE autoantibodies binding with native DNA, native $\mathrm{H} 3$ and peroxynitritemodified $\mathrm{H} 3$ histone were investigated to explore peroxynitrite-modified $\mathrm{H} 3$ histone as likely trigger for the origin of anti-histone autoantibodies or its involvement in the progression of the disease in a sub-group of SLE patients.

\section{Materials and methods}

\subsection{Materials}

Calf thymus $\mathrm{H} 3$ histone, human serum albumin, low density lipoprotein, catalase, trypsin, tryptophan, phenylalanine, superoxide dismutase, 3-nitrotyrosine, Protein A-agarose affinity column, p-nitrophenyl phosphate, Tween20, Freund's complete and incomplete adjuvants and diethylenepenta-acetic acid (DTPA) were obtained from Sigma Chemical Company, St. Louis, MO, USA. Yeast RNA was from BDH Chemicals Ltd, England. Sodium nitrite, hydrogen peroxide, silver nitrate, sodium hydroxide and ammonium persulphate were obtained from Qualigens, India. Flat bottom polysorp ELISA modules were purchased from NUNC, Denmark. All other reagents were of highest analytical grade available.

\subsection{Methods}

\subsubsection{Modification of $\mathbf{H 3}$ histone by peroxynitrite}

Peroxynitrite was synthesized in laboratory by rapid quenched flow process from sodium nitrite (Merck, Darmstadt, Germany) and acidified hydrogen peroxide (Merck, Darmstadt, Germany) [16] and stored in $1.2 \mathrm{M} \mathrm{NaOH}$ at $-20^{\circ} \mathrm{C}$. Before each use, the concentration of stored peroxynitrite was determined by recording absorbance at $302 \mathrm{~nm}$ using molar extinction 
coefficient of $1670 \mathrm{M}^{-1} \mathrm{~cm}^{-1}$. The modification was carried out by incubating $25 \mu \mathrm{M}$ of $\mathrm{H} 3$ histone in a buffer $(10 \mathrm{mM}$ sodium phosphate buffer, pH 7.4 containing $150 \mathrm{mM} \mathrm{NaCl}$ and 100 $\mu \mathrm{M}$ DTPA) with different amount of peroxynitrite $(50,100$ and $200 \mu \mathrm{M})$ at $37^{\circ} \mathrm{C}$ for $30 \mathrm{~min}$. The approximate $\mathrm{pH}$ of the incubation mixture was in the range of 10-11. Unmodified H3 histone served as a control.

\subsubsection{Immunization schedule}

Female New Zealand white rabbits weighing 1-1.5 $\mathrm{kg}$ were selected for immunization [17]. Briefly, rabbits $(n=4$; two each for native and peroxynitrite-modified H3 histone) were given intramuscular injections of $\mathrm{H} 3$ histone $(200 \mu \mathrm{g})$ or its peroxynitrite-modified counterparts at multiple sites. Before injecting into animals, the respective immunogens were complexed with yeast RNA (one-third of immunogen concentration) and emulsified with equal volume of Freund's complete adjuvant (first injection). Subsequent injections of immunogen were given in Freund's incomplete adjuvant at weekly intervals. During the course of immunization, each animal received a total of $1200 \mu \mathrm{g}$ of immunogen. A similar course of immunization was followed with RNA alone $(66.5 \mu \mathrm{g})$. One week after the last dose, marginal ear veins of the animals were punctured and blood was carefully collected. The separated sera were heated at $56^{\circ} \mathrm{C}$ for $30 \mathrm{~min}$ to inactivate complement proteins and stored at $-20{ }^{\circ} \mathrm{C}$ with $0.1 \%$ sodium azide as preservative.

\subsubsection{Serum samples}

SLE sera $(n=50)$ were collected from female patients (18-50 years of age) attending speciality clinic at the All India Institute of Medical Sciences, New Delhi. Consent was obtained from all patients before blood was collected. All SLE patients satisfied the American College of Rheumatology criteria [18] and showed high-titer anti-nDNA autoantibodies $(>1: 12,800)$. No patient had active infection, known malignancy, tuberculosis, pregnancy, or liver cirrhosis. Control sera were obtained from 25 age- and sex- matched non-smoking healthy female volunteers. All serum samples were decomplemented by heating at $56^{\circ} \mathrm{C}$ for $30 \mathrm{~min}$ and stored in aliquots at $-80^{\circ} \mathrm{C}$.

\subsubsection{Enzyme linked immunosorbent assay (ELISA)}

Direct binding ELISA was carried out on flat bottom polystyrene plates as described earlier [19] with slight modifications. Antibody specificity was ascertained by inhibition ELISA [20]. Percent inhibition was calculated as follows:

$$
\text { Percent inhibition }=1-\frac{\mathrm{A}_{\text {inhibited }}}{\mathrm{A}_{\text {uniniited }}} \mathrm{X} 100
$$

\subsubsection{Purification of IgG on Protein A-agarose matrix}

Immunoglobulin $\mathrm{G}$ ( $\mathrm{IgG}$ ) was affinity purified from preimmune and immune sera on a Protein A-agarose column [21]. The homogeneity of isolated IgG was ascertained on $7.5 \% \mathrm{SDS}$ PAGE.

\subsubsection{Band shift assay}

For the visual detection of antigen-antibody interactions and immune complex formation, a gel retardation assay was performed [20]. Immune complex was prepared by incubating constant amount of native or peroxynitritemodified $\mathrm{H} 3$ histone with varying amounts of affinity purified anti-peroxynitrite-modified $\mathrm{H} 3$ IgG in PBS for $2 \mathrm{~h}$ at $37^{\circ} \mathrm{C}$ and overnight at $4^{\circ} \mathrm{C}$. One-fourth volume of sample dye buffer $(0.1 \%$ glycerol, $0.5 \mathrm{M}$ Tris, $10 \%$ SDS and $1 \%$ bromophenol blue, $\mathrm{pH}$ 6.8) was added to the mixture and electrophoresed on $10 \%$ nonreducing SDS-polyacrylamide gel for $4 \mathrm{~h}$ at $80 \mathrm{~V}$. The bands were visualized by silver nitrate.

\subsubsection{Statistical analysis}

Data are presented as mean \pm standard deviation (SD). Statistical significance of data was determined by Student's t test, and a $p$ value of $<0.05$ was considered significant.

\section{Results}

\subsection{Characterization of $\mathrm{H3}$ histone modified by peroxynitrite}


Our previous study [22] has shown structural alterations in $\mathrm{H} 3$ histone following exposure to peroxynitrite. The changes were studied by UV and fluorescence spectroscopy, 8anilino-1-naphthalenesulfonic acid binding, FTIR, CD and PAGE. Analysis of the data revealed that carbonyl, nitrotyrosine, and dityrosine contents were significantly increased in peroxynitrite-modified $\mathrm{H} 3$ histone.

\subsection{Immunogenicity of native and peroxynitrite-modified $\mathrm{H3}$ histone}

Sera of animals immunized with native and peroxynitrite-modified $\mathrm{H} 3$ were tested on polysorp wells coated with respective immunogens. Antiserum against $50 \mu \mathrm{M}$ peroxynitrite-modified $\mathrm{H} 3$ showed an antibody titre of 1:3200 (Fig. 1). Modification by $100 \mu \mathrm{M}$ peroxynitrite of $\mathrm{H} 3$ histone resulted in substantial enhanced immunogenicity with a titre of 1:12800. Native H3 induced moderate antibody response. Yeast RNA used as carrier was nonimmunogenic. Preimmune serum, used as negative control, showed weak binding with the immunogen. As modification of $\mathrm{H} 3$ histone by $100 \mu \mathrm{M}$ peroxynitrite gave better antibody response, further studies were carried out with this antibody. Our results suggest that modification of $\mathrm{H} 3$ histone by peroxynitrite generates highly immunogenic neo-epitopes on the $\mathrm{H} 3$ histone.

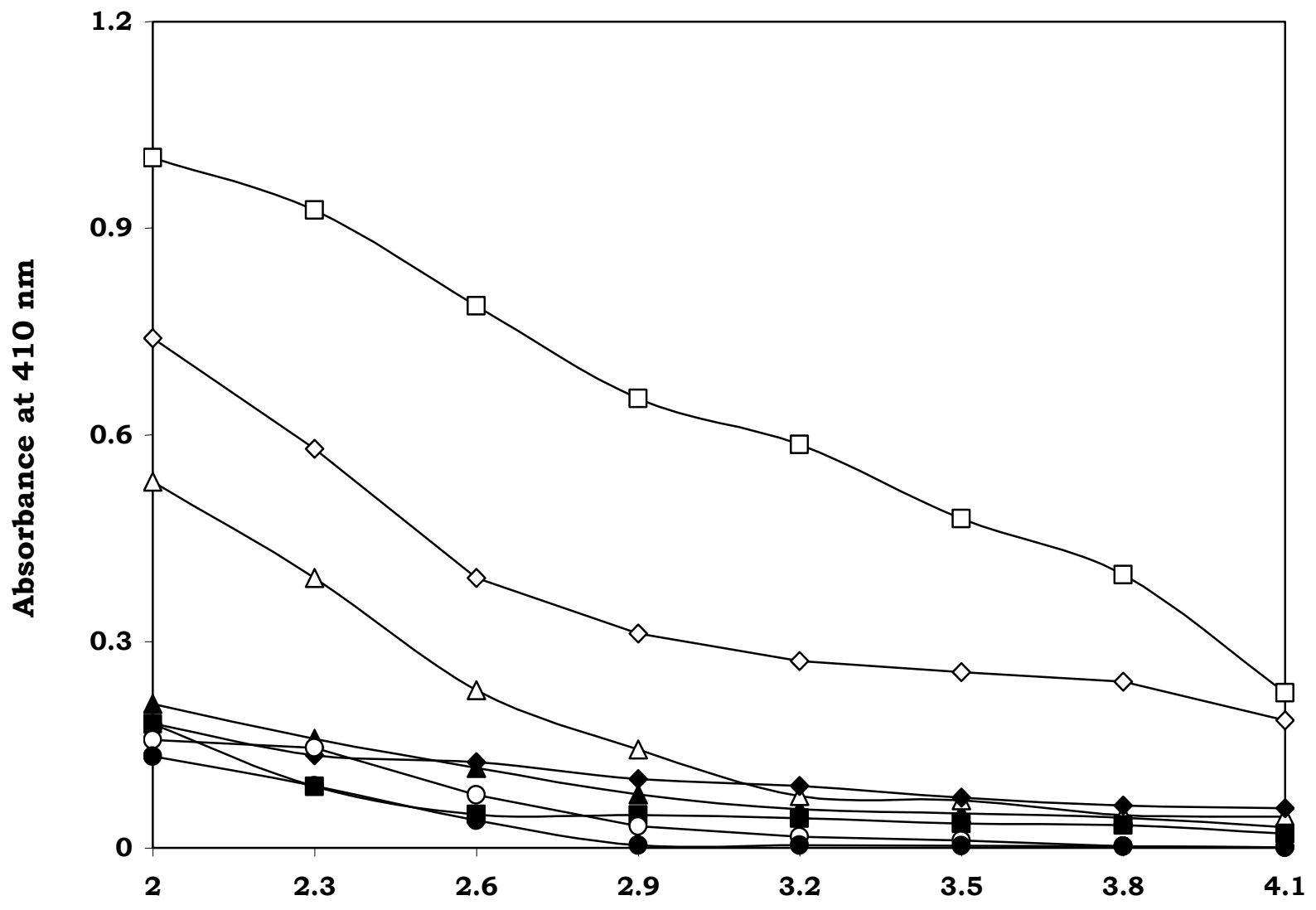

-Log of serum dilution

Figure 1. Direct binding ELISA of experimentally produced antibodies against $100 \mu \mathrm{M}$ peroxynitrite-modified H3 $(-\square-), 50 \mu \mathrm{M}$ peroxynitrite-modified $\mathrm{H} 3(-\diamond-)$, native $\mathrm{H} 3(-\Delta-)$ and yeast RNA (-०). The corresponding filled symbols show preimmune sera binding with respective immunogens coated on microtitre wells. 


\subsection{Characterization of anti-100 $\mu \mathrm{M}$ peroxynitrite-modified $\mathrm{H} 3$ IgG}

IgG purified from $100 \mu \mathrm{M}$ peroxynitritemodified $\mathrm{H} 3$ histone antisera were subjected to direct binding immunoassay on wells coated with $100 \mu \mathrm{M}$ peroxynitrite-modified $\mathrm{H} 3$ histone. Anti$100 \mu \mathrm{M}$ peroxynitrite-modified $\mathrm{H} 3 \mathrm{IgG}$ showed strong binding with coated antigen (Fig. 2). Preimmune IgG showed negligible binding under identitical conditions. Specificity of anti-100 $\mu \mathrm{M}$ peroxynitrite-modified $\mathrm{H} 3 \mathrm{IgG}$ was evaluated by inhibition ELISA using immunogen as inhibitor. The induced antibodies were highly specific for the immunogen (Fig. 3).

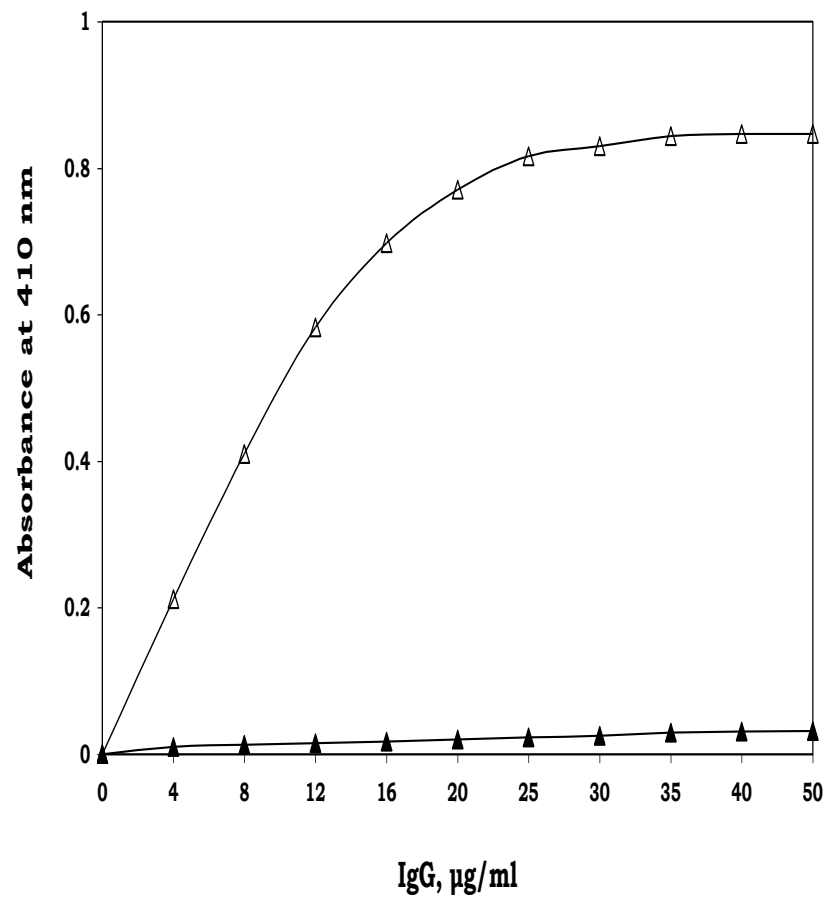

Figure 2. Direct binding of affinity purified immune $\operatorname{IgG}(-\Delta-)$ and preimmune $\operatorname{IgG}(-\boldsymbol{\Delta}-)$. The microtitre wells were coated with $100 \mu \mathrm{M}$ peroxynitrite-modified $\mathrm{H} 3$.

\subsection{Use of anti-100 $\mu \mathrm{M}$ peroxynitrite-modified H3 IgG antibodies to study epitope sharing by other proteins modified by peroxynitrite}

Native $\mathrm{H} 3$ used as inhibitor of anti- $100 \mu \mathrm{M}$ peroxynitrite-modified $\mathrm{H} 3 \quad \mathrm{IgG}$ showed $51 \%$ inhibition in antibody binding. Binding of anti$100 \mu \mathrm{M}$ peroxynitrite-modified $\mathrm{H} 3 \quad \mathrm{IgG}$ antibodies was also carried out with an array of peroxynitrite-modified proteins including $\mathrm{H} 2 \mathrm{~A}$,
H2B and H1 histones. Results of cross-reaction studies have been summarized in Table 1. The data suggests that nitrated epitopes of different proteins (or amino acids) share common properties. Furthermore, among peroxynitritemodified amino acids, nitrated-tyrosine showed $68 \%$ inhibition in antibody binding followed by nitrated-phenylalanine and nitrated-tryptophan. Participation of nitrated-tyrosine (nitrotyrosine) as preferred substrate for induced antibodies points out the significance of nitrotyrosine in immunogenicity.

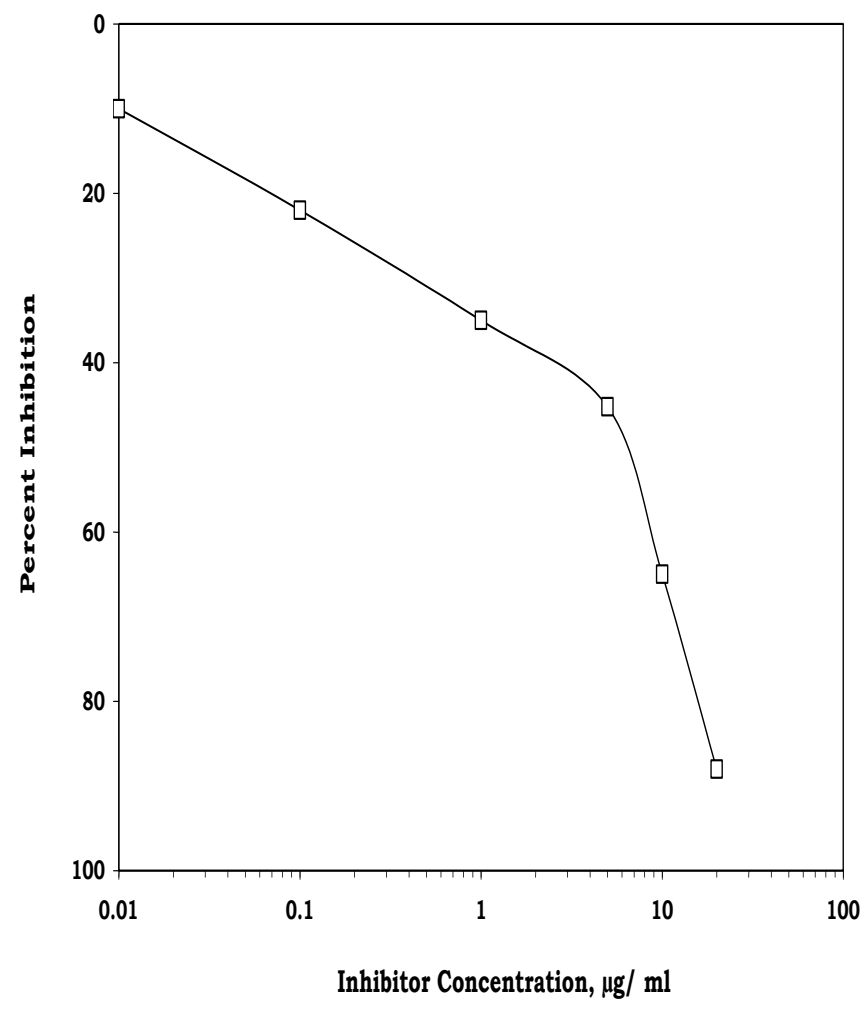

Figure 3. Inhibition of binding of anti-peroxynitritemodified $\mathrm{H} 3 \mathrm{IgG}$ by $100 \mu \mathrm{M}$ peroxynitrite-modified H3. The microtitre wells were coated with $\mathrm{H} 3$ modified by $100 \mu \mathrm{M}$ peroxynitrite.

3.5 Direct binding ELISA of SLE sera with native DNA, native $\mathrm{H3}$ and $100 \mu \mathrm{M}$ peroxynitrite-modified $\mathrm{H3}$

All 50 SLE sera included in this study were pre-tested for anti-native DNA autoantibodies and found to be antibody positive. Age- and sexmatched sera from apparently healthy individuals served as controls. The diluted $(1: 100)$ sera were subjected to direct binding ELISA on microtiter wells separately coated with equal amounts of 
native DNA, native $\mathrm{H} 3$ histone, and $100 \mu \mathrm{M}$ peroxynitrite-modified $\mathrm{H} 3$ histone (Fig. 4). Approximately $60 \%$ of tested SLE sera showed higher binding with peroxynitrite-modified H3 histone compared to native DNA or native $\mathrm{H} 3$ histone. No appreciable binding was observed with the pooled sera of normal subjects. These observations are important in view of the immunogenicity of peroxynitrite-modified $\mathrm{H} 3$ histone and the reported incidence of hypernitrotyrosinemia and anti-histone antibodies in a sun-group of SLE patients (7).

Table 1. Cross reaction of peroxynitrite-modified H3 IgG antibodies ${ }^{\#}$

\begin{tabular}{lc}
\hline Inhibitors & $\begin{array}{c}\text { Maximum percent } \\
\text { inhibition at } \mathbf{2 0} \boldsymbol{\mu} \mathbf{g} / \mathbf{m l}\end{array}$ \\
\hline Nitrated-H3 & 88 \\
Native H3 & 51 \\
Nitrated-H2A & 70 \\
Native H2A & 39 \\
Nitrated-H2B & 62 \\
Native H2B & 44 \\
Nitrated-H1 & 58 \\
Native H1 & 27 \\
Nitrated-human IgG & 66 \\
Native human IgG & 31 \\
3-nitrotyrosine & 68 \\
Tyrosine & 33 \\
Nitrated-SOD & 29 \\
SOD & 10 \\
Nitrated-HSA & 64 \\
HSA & 22 \\
Nitrated-Catalase & 58 \\
Catalase & 28 \\
Nitrated-LDL & 59 \\
LDL & 27 \\
Nitrated-Trypsin & 56 \\
Trypsin & 19 \\
Nitrated-Tryptophan & 13 \\
Tryptophan & 06 \\
Nitrated- & 20 \\
Phenylalanine & \\
Phenylalanine & 07 \\
\hline Wellswerecoated & \\
\hline
\end{tabular}

${ }^{\#}$ Wells were coated with $100 \mu \mathrm{M}$ peroxynitritemodified $\mathrm{H} 3$ histone.

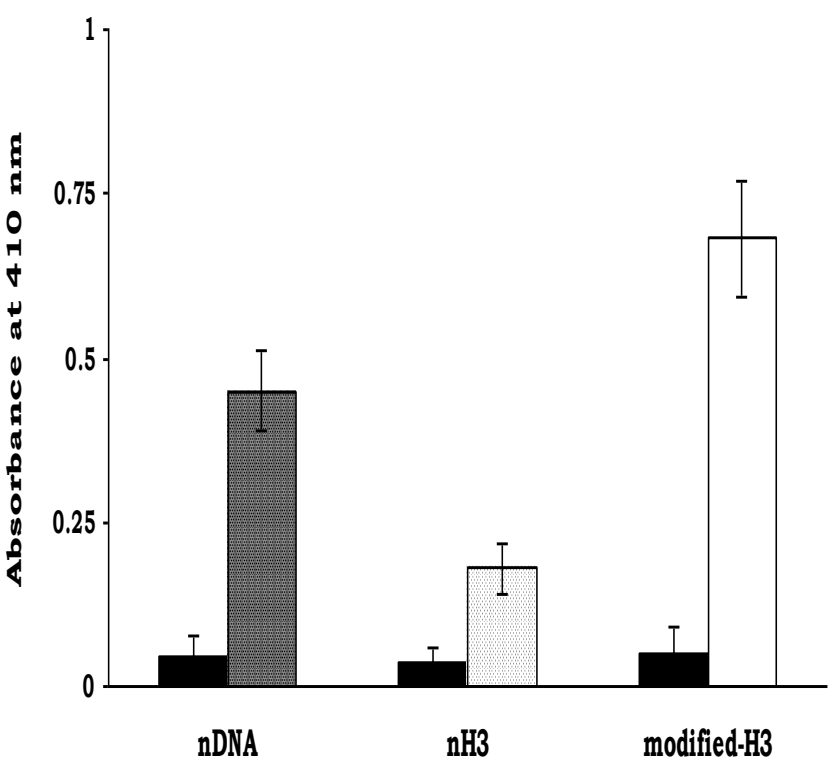

Figure 4. Direct binding of 1:100 diluted SLE sera

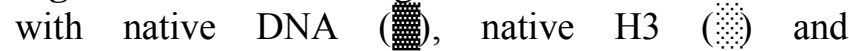
peroxynitrite-modified $\mathrm{H} 3 \quad(\square)$. The histograms represent mean \pm S.D. of 50 SLE sera. Filled bars represent mean \pm S.D of 35 control human sera binding with corresponding antigens.

\subsection{Inhibition ELISA of SLE IgG with native DNA, native $\mathrm{H3}$, and $100 \mu \mathrm{M}$ peroxynitrite- modified $\mathrm{H} 3$}

IgG were purified from 20 active SLE sera that showed higher binding with peroxynitritemodified $\mathrm{H} 3$ histone in direct-binding ELISA. The fine antigenic specificity of isolated SLE IgG was evaluated using native DNA, native $\mathrm{H} 3$, and $100 \mu \mathrm{M}$ peroxynitrite-modified $\mathrm{H} 3$ as inhibitors. Purified SLE IgG was separately mixed with DNA, H3, and $100 \mu \mathrm{M}$ peroxynitrite-modified $\mathrm{H} 3(0-20 \mu \mathrm{g} / \mathrm{mL})$ and incubated for $2 \mathrm{~h}$ at $37^{\circ} \mathrm{C}$ and overnight at $4{ }^{\circ} \mathrm{C}$. The resulting complex was coated instead of IgG. The remaining steps were the same as described for direct-binding ELISA. The interaction of inhibitors with different SLE IgG has been represented as the percentage inhibition in antibody binding (Table 2). The peroxynitrite-modified $\mathrm{H} 3$ histone emerged as the most effective inhibitor, followed by native DNA and native $\mathrm{H} 3$. Inter comparison of the data using a statistical method yielded a $p$ value $<0.001$ for peroxynitrite-modified $\mathrm{H} 3$ versus native DNA or native histone, which indicates that the data are statistically significant. The immunogenic nature 
of peroxynitrite-modified $\mathrm{H} 3$ and the reported incidence of anti-histone antibodies and hypernitrotyrosinemia in SLE patients advocate a possible role of peroxynitrite-modified $\mathrm{H} 3$ histone in SLE initiation, at least in a subpopulation of patients.

Table 2. "Inhibition of SLE IgG binding by native DNA, native $\mathrm{H3}$ and peroxynitrite-modified $\mathrm{H}$

\begin{tabular}{|c|c|c|c|}
\hline \multirow{2}{*}{$\begin{array}{l}\text { SLE } \\
\text { IgG }\end{array}$} & \multicolumn{3}{|c|}{$\begin{array}{c}\text { Maximum percent inhibition at } 20 \\
\mu \mathrm{g} / \mathrm{ml}\end{array}$} \\
\hline & nDNA & nH3 & $\begin{array}{c}\text { Peroxynitrite- } \\
\text { modified H3 }\end{array}$ \\
\hline $01(2)$ & 50.8 & 20.0 & 70.3 \\
\hline $02(3)$ & 57.4 & 30.0 & 69.2 \\
\hline $03(4)$ & 56.0 & 28.0 & 73.7 \\
\hline 04 (15) & 49.8 & 32.0 & 65.4 \\
\hline 05 (16) & 45.8 & 34.0 & 66.5 \\
\hline $06(17)$ & 46.5 & 26.0 & 69.7 \\
\hline $07(21)$ & 53.5 & 27.0 & 75.2 \\
\hline $08(22)$ & 47.0 & 30.0 & 70.0 \\
\hline $09(23)$ & 45.8 & 24.0 & 68.7 \\
\hline $10(24)$ & 49.3 & 31.0 & 69.2 \\
\hline $11(25)$ & 51.7 & 22.0 & 68.7 \\
\hline $12(26)$ & 54.6 & 21.0 & 70.2 \\
\hline 13 (29) & 58.0 & 37.0 & 72.4 \\
\hline $14(30)$ & 50.0 & 20.0 & 64.0 \\
\hline $15(33)$ & 44.0 & 18.0 & 64.5 \\
\hline $16(34)$ & 52.0 & 24.0 & 76.1 \\
\hline $17(35)$ & 56.0 & 26.0 & 75.4 \\
\hline $18(42)$ & 58.8 & 32.0 & 82.3 \\
\hline 19 (49) & 52.0 & 36.0 & 60.0 \\
\hline $20(50)$ & 43.2 & 28.0 & 63.7 \\
\hline
\end{tabular}

Mean \pm SD $\quad(51.11 \pm 4.75) \quad(27.30 \pm 5.49) \quad(67.77 \pm 5.79)$

"Microtitre plates were coated with native DNA $(2.5 \mu \mathrm{g} / \mathrm{ml})$ nDNA = native DNA; $\quad \mathrm{nH} 3=$ native $\mathrm{H} 3$ histone Numbers in parenthesis indicates the SLE sera that showed higher binding with peroxynitrite-modified $\mathrm{H} 3$ histone in direct binding ELISA.
(A)

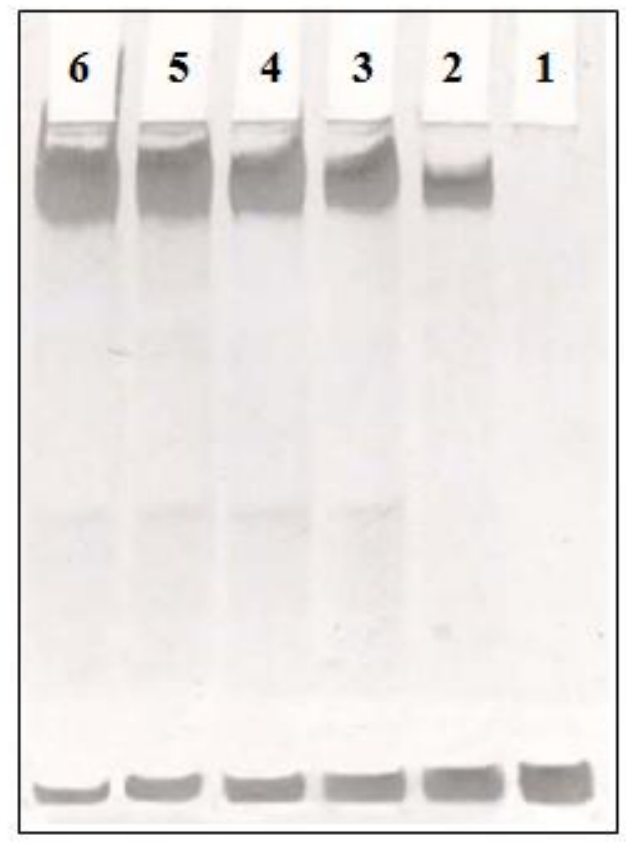

(B)

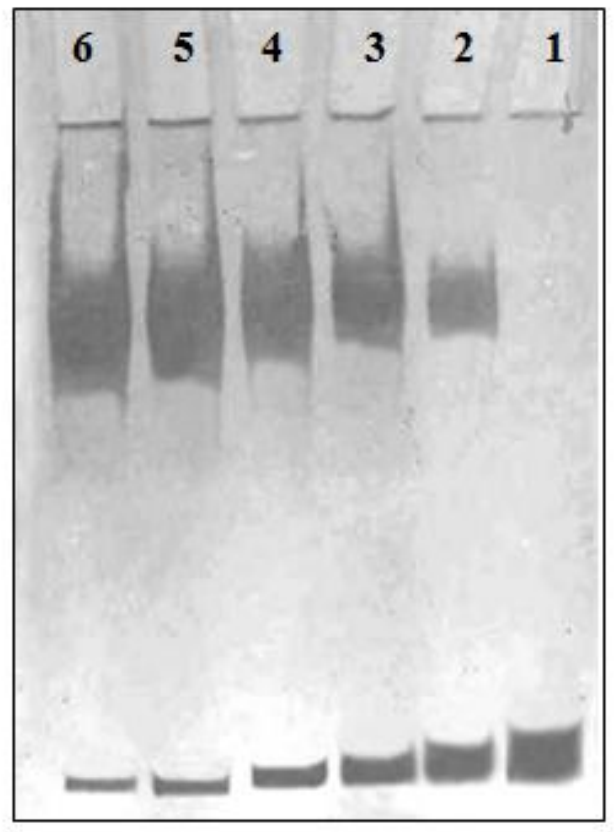

Figure 5. Gel retardation assay of an SLE IgG with native and peroxynitrite-modified H3 histone in SDSpolyacrylamide gel. Electrophoresis was performed on $10 \%$ SDS-polyacrylamide gel for $4 \mathrm{~h}$ at 80 Volts. (A) Native $\mathrm{H} 3(25 \mu \mathrm{g}$, lane 1) was incubated with 20,30 , 40,60 and $80 \mu \mathrm{g}$ of SLE IgG (lanes 2-6) and incubated for $2 \mathrm{~h}$ at $37^{\circ} \mathrm{C}$ and overnight at $4^{\circ} \mathrm{C}$. (B) $100 \mu \mathrm{M}$ peroxynitrite-modified $\mathrm{H} 3(25 \mu \mathrm{g}$, lane 1$)$ was incubated with $20,30,40,60$ and $80 \mu \mathrm{g}$ of SLE IgG (lanes 2-6) and incubated under identical conditions. 


\subsection{Gel retardation assay with SLE IgG}

The antigen-antibody interaction was also visualized in non-reducing SDS-polyacrylamide gel. The formation of immune complex between $100 \mu \mathrm{M}$ peroxynitrite-modified $\mathrm{H} 3$ histone and SLE IgG was clearly evident from the retarded mobility of the complex with increasing concentrations of SLE IgG (Fig. 5B) as compared to antigen alone (Lane 1; Fig. 5B). The proportional decrease in free antigen intensity was accompanied by increase in the mass of immune complex which reiterates the specific antigen-antibody interaction. Under identical conditions interaction of native $\mathrm{H} 3$ histone with SLE IgG was moderate (Fig. 5A). Formation of large immune complex of SLE IgG and $100 \mu \mathrm{M}$ peroxynitrite-modified $\mathrm{H} 3$ histone was clearly seen as compared to native $\mathrm{H} 3$.

\section{Discussion}

SLE is a complex autoimmune inflammatory disease. Despite decades of extensive research on SLE, the exact nature of antigen stimulus for initiation and progression of the diseases remains unknown. Endogenous proteins are normally not immunogenic due to immunological tolerance. However, posttranslational modifications of self-proteins may lead to the generation or unmasking of epitopes, resulting in the triggering of immune response, which may induce autoimmunity [5]. Studies on the recognition of tyrosine nitrated proteins by $\mathrm{T}$ cells showed that protein nitration of a tyrosyl residue(s) in a T-cell receptor (TCR) contact position may result in the formation of an immunogenic neoepitope [24,6]. Moreover, it was shown that nitration of tyrosine residues located in non-TCR-contact positions can have an indirect yet major impact on stimulation of the immune system by affecting interactions of the TCR with the peptide-loaded major histocompatibility complex [23].

Autoantibodies against intracellular proteins and nucleic acids are serological hallmark of the systemic rheumatic diseases such as SLE, Progressive systemic sclerosis (PSS), Sjogren's syndrome (SS), mixed connective tissue diseases (MCTD) and polymyositis (PM) [24]. Each of these diseases is identified by the unique autoantibodies. Antibodies to dsDNA serve as an immunological marker for the diagnosis of SLE [25]. These autoimmune diseases are associated with multiple antinuclear antibody specificities, suggesting a role for both generalized as well as antigen-specific immune abnormalities in their etiology [26,27].

Histones are small, cationic proteins which bind DNA. They are weak immunogen because of their conserved nature. Histones are major constituent of cells' chromatin and remain confined to nucleus. However, after apoptosis they may appear in circulation as nucleosomes. Anti-histone antibodies are autoantibodies that are found in $50 \%-70 \%$ of patients with SLE and in more than $95 \%$ of patients with drug-induced SLE [28].

Our study demonstrated that modification of $\mathrm{H} 3$ histone by peroxynitrite resulted in tyrosine nitration, formation of protein carbonyl, dityrosine and cross-linking. The structural changes appear to have favoured polymerization of native epitopes of $\mathrm{H} 3$ histone into potent immunogenic neo-epitopes. Earlier studies have shown that acetylation, alterations in amino acid structure or sequence can generate neo-epitopes on self proteins causing autoaggressive immune attack [29]. Interpretation of our results in the light of above suggests that oxidative and nitrative action of peroxynitrite has conferred additional immunogenicity on $\mathrm{H} 3$ histone and probably there is a direct correlation between nitration and immunogenicity. The $\mathrm{H} 3$ histone modified by $100 \mu \mathrm{M}$ peroxynitrite was a potent immunogen and induced high titre antibodies in rabbits. Although anti-100 $\mu \mathrm{M}$ peroxynitritemodified $\mathrm{H} 3$ antibodies showed specificity for the immunogen but cross reacted with native $\mathrm{H} 3$. It indicates that not all epitopes typical of $\mathrm{H} 3$ histone have been converted into neoepitopes upon nitration. In another words, peroxynitritemodified H3 still has some original epitopes which are scattered among neo-epitopes. Hence, immunization with peroxynitrite-modified $\mathrm{H} 3$ may produce polyspecific antibodies which can recognize both original and neo-epitopes or altogether there are two types of antibodies, one recognizing nitrated neo-epitopes and other 
binding exclusively with old epitopes. Accumulation of a variety of post-translationally modified self-proteins during inflammation may lead to generation or unmasking of new antigenic epitopes that in turn activate B-and /or T-cells, thereby impairing or bypassing immunological tolerance [30]. Against this backdrop, peroxynitrite-modified $\mathrm{H} 3$ histone could act as an autoantigen leading to generation of anti-H3 histone antibodies.

We further investigated the binding characteristics of naturally occurring SLE antiDNA autoantibodies to native calf thymus DNA and native and peroxynitrite-modified-H3 histone. Sera of SLE patients, having high titre anti-DNA antibodies, showed preference for peroxynitrite-modified $\mathrm{H} 3$ histone compared to native $\mathrm{H} 3$ histone or native DNA. This suggests that peroxynitrite-modified $\mathrm{H} 3$ histone is an effective inhibitor of native DNA-anti-DNA antibody interaction. Band shift assay and inhibition ELISA with SLE IgG substantiated the preferential binding of peroxynitrite--modified $\mathrm{H} 3$ histone with SLE autoantibodies. It may be interpreted that nitration of tyrosine residues resulted in generation of neoantigen(s) with explicit immune response compared to native $\mathrm{H} 3$ histone. The body's immunosurveillance may prove ineffective if the generation of peroxynitrite is enhanced tremendously, as seen in chronic inflammation and in injured tissues. Once peroxynitrite level increases, the damage and nitration would be inevitable and the immunoregulatory network would be activated resulting in the production of autoantibodies. Cellular metabolism and ionization radiation produces both reactive nitrogen and oxygen species. These radicals and their subsequent intermediates may react with cellular macromolecules and induce a variety of chemical alterations leading to autoantibodies [31]. In SLE, reactive nitrogen intermediates are over produced due to over expression of inducible nitric oxide synthase (iNOS) which may lead to tissue injury and increase carbonyl groups in a sub-group of SLE patients. The mechanism through which peroxynitrite can be pathogenic in the setting of SLE is through the generation of neo-epitopes on self antigens. Serum from SLE patients exhibited increased binding to peroxynitrite--modified $\mathrm{H} 3$ histone compared to native DNA or native $\mathrm{H} 3$ histone. The present studies suggest that peroxynitrite modification of $\mathrm{H} 3$ histone can generate highly immunogenic neo-epitopes generating autoantibodies recognizing native $\mathrm{H} 3$ histone as seen in a sub-group of SLE patients.

\section{Acknowledgement}

This study was supported by a research grant (52/11/2003-BMS) to K.A. from the Indian Council of Medical Research, New Delhi. Authors also acknowledge the infrastructure facilities of DST-FIST.

\section{Bibliography}

1. Pryor, W.A.; Squandrito, G.I. Chemistry of peroxynitrite: a product from the reaction of nitric oxide with superoxide. Am. J. Physiol, 1995, 268, L699-722.

2. Ohshima, H.; Friesen, M.; Brouet, I.; Bartsch, H. Nitrotyrosine as a new marker for endogenous nitrosation and nitration of proteins. Food Chem. Toxicol, 1990, 28, 647-652. DOI: $\quad \underline{10.1016 / 0278-}$ 6915(90)90173-K

3. Muller, S.; Isabey, A.; Cooppez, M.; Plaue, S.; Sommermeyer, G.; Van Regenmortel, M.H. Specificity of antibodies raised against triacetylated histone H4. Mol. Immunol, 1987, 24,779-789. DOI: 10.1016/01615890(87)90062-9

4. Atanassov, C.; Briand, J.P.; Bonnier, D.; Van Regenmortel, M.H.; Muller, S. New Zealand white rabbits immunized with RNAcomplexed total histone develop an autoimmune like response. Clin. Exp. Immunol, 1991, 86, 124-33. DOI: 10.1111/j.1365-2249.1991.tb05784.X

5. Ohmori, H.; Kanayama, N. Immunogenicity of an inflammation associated product, tyrosine nitrated self proteins. Autoimmun. Rev, 2005, 4, 224-229. DOI: 10.1016/j.autrev.2004.11.011

6. Birnboim, H.C.; Lemay, A.M.; Lam, D.K.; Goldstein, R.; Webb, J.R. Cutting edge: MHC 
class II-restricted peptides containing the inflammation associated marker 3nitrotyrosine evade central tolerance and elicit a robust cell mediated immune response. J. Immunol, 2003, 171, 528-532.

7. Khan, F.; Siddiqui, A.A. Prevalence of anti-3nitrotyrosine antibodies in the joint synovial fluid of patients with rheumatoid arthritis, osteoarthritis and systemic lupus erythematosus. Clin. Chim. Acta, 2006, 370, 100-107. DOI: $10.1016 /$ j.cca.2006.01.020

8. Khan, F.; Ali, R. Antibodies against nitric oxide damaged poly L-tyrosine and 3nitrotyrosine levels in systemic lupus erythematosus. J. Biochem. Mol. Biol, 2006, 39, 189-196. DOI: 10.5483/BMBRep.2006.39.2.189

9. Van Bavel, C.C.; van der Vlag, J.; Berden, J.H. Nucleosome-specific autoantibodies. In: Shoenfeld Y, Gershwin ME, Meroni PL, eds. Autoantibodies. 2nd ed. Amsterdam: Elsevier, 2007, 197-204.

10. Licht, R.; Dieker, J.W.; Jacobs, C.W. Decreased phagocytosis of apoptotic cells in diseased SLE mice. J. Autoimmun, 2004, 22, 139-145. DOI: $\underline{10.1016 / j . j a u t .2003 .11 .003}$

11. Herrmann, M.; Voll, R.E.; Zoller, O.M. Impaired phagocytosis of apoptotic cell material by monocyte-derived macrophages from patients with systemic lupus erythematosus. Arthritis Rheum, 1998, 41, 1241-1250. DOI: 10.1002/1529-0131(199807) 41:7<1241::AID-ART15>3.0.CO;2-H

12. Licht, R.; van Bruggen, M.C.; OppersWalgreen, B. Plasma levels of nucleosomes and nucleosome-autoantibody complexes in murine lupus: effects of disease progression and lipopolyssacharide administration. Arthritis Rheum, 2001, 44, 1320-1330. DOI: 10.1002/1529-0131(200106)44:6<1320::

\section{AID-ART224>3.0.CO;2-X}

13. Dumortier, H.; Muller, S. Histone autoantibodies. In Textbook of autoantibodies, 2nd ed. Y. Shoenfeld, P. L. Meroni, P.L., and E. Gershwin, eds. Elsevier, Amsterdam, 2006, 169-176.

14. Belmont, H.M.; Levartovsky, D.; Goel, A. Increased nitric oxide production accompanied by the upregulation of inducible nitric oxide synthase in vascular endothelium from patients with systemic lupus erythematosus. Arthritis Rheum, 1997, 40, 1810-1816. DOI: $\underline{10.1002 / a r t .1780401013}$

15. Wanchu, A.; Khuller, M.; Deodhar, S.D. Nitric oxide synthesis is increased in patients with systemic lupus erythematosus. Rheumatol. Int, 1998, 18, 41-43. DOI: $10.1007 / \mathrm{s} 002960050055$

16. Koppenol, W.H.; Kissner, R.; Beckman, S.; Synthesis of peroxynitrite: to go with the flow or on solid grounds? Methods Enzymol, 1996. 269, 296-302. DOI: 10.1016/S00766879(96)69030-2

17. Bustin, M.; Stollar, B.D. Immunochemical specificity in lysine-rich histone subfractions. J. Biol. Chem, 1972, 247, 5716-5721.

18. Arnett, F.C.; Edworthy, S.M.; Bloch, D.A.; McShane, D.J.; Fries, J.F.; Cooper, N.S.; Healy, L.A.; Kaplan, S.R. Liang, M.H.; Luthra, H.S.; Medsagar, T.AJr.; Mitchell, D.M, Neustadt, D.H.; Pinals, R.S.; Schaller, J.G.; Sharp, J.T.; Wilser, R.L.; Hunder, G.G. The American Rheumatism Association 1987 revised criteria for the classification of rheumatoid arthritis. Arthritis Rheum, 1988, 31, 315-324. DOI: 10.1002/art.1780310302

19. Khan, M.A.; Dixit, K.; Jabeen, S.; Moinuddin; Alam, K. Impact of Peroxynitrite Modification Structure and Immunogenicity of H2A Histone. 2008, Scand. J. Immunol, 69, 99-109. DOI: $\underline{10.1111 / \mathrm{j} .1365-}$ 3083.2008.02200.x

20. Dixit, K.; M. A. Khan; Sharma, Y.D.; Moinuddin; Alam, K. Peroxynitrite-induced modification of $\mathrm{H} 2 \mathrm{~A}$ histone mimics epitopes which are strongly bound by human antiDNA autoantibodies: Role of peroxynitritemodified-H2A in SLE induction and progression. Human Immunol, 2011, 72, 219-225. DOI: 10.1016/j.humimm.2010.12.004

21. Alam, K.; Moinuddin; Jabeen, S. Immunogenicity of mitochondrial DNA modified by hydroxyl radical. Cell. Immunol, 2007, 247, 12-17. DOI: 10.1016/j.cellimm.2007.06.007

22. Dixit, K.; M.A. Khan; Sharma, Y.D.; Moinuddin; Alam, K. Physicochemical studies on peroxynitrite-modified H3 histone. 
Int. J. Biol. Macromol, 2010, 46, 20-26. DOI: 10.1016/j.ijbiomac.2009.10.009

23. Hardy, L.L.; Wick, D.A.; Webb, J.R. Conversion of tyrosine to the inflammation associated analog 3'-nitrotyrosine at either TCR- or MHC-contact positions can profoundly affect recognition of the MHC class I-restricted epitope of lymphocytic choriomeningitis virus glycoprotein 33 by CD8 T cells. J. Immunol, 2008, 180, 59565962.

24. Shoenfeld, Y.; Segol, O. Anti-histone antibodies in SLE and other autoimmune diseases. Clin. Exp. Rheumatol, 1989. 7, 265271.

25. Su,Y.; Jia, R.L.; Han, L.; Li, Z.G._Role of anti-nucleosome antibody in the diagnosis of systemic lupus erythematosus. Clin. Immunol, 2007. 122, 115-120. DOI: 10.1016/j.clim.2006.10.003

26. Pisetsky, D.S. Anti-DNA antibodies in systemic lupus erythematosus. Rheum. Dis. Clin. North Am, 1992, 18, 437-454.

27. Herrmann, M.; Winkler, T.H.; Fehr, H.; Kalden, J.R. Preferential recognition of specific DNA motifs by anti-double-stranded
DNA autoantibodies. Eur. J. Immunol, 1995, 25, 1897-1904. DOI: 10.1002/eji.1830250716

28. Mitchell, R.S.; Kumar, V.; Abbas, A.K.; Fausto, N. Robbins Basic Pathology. Philadelphia: Saunders. 2007, ISBN 1-41602973-2977, 8th ed.

29. Muller, S.; Isabey, A.; Cooppez, M.; Plaue, S.; Sommermeyer, G.; Van Regenmortel, M.H. Specificity of antibodies raised against triacetylated histone H4. Mol. Immunol, 1987, 24, 779-789. DOI: 10.1016/0161$\underline{5890(87) 90062-9}$

30. Ohmori H, Kanayama N. Immunogenicity of an inflammation-associated product, tyrosine nitrated self-proteins. Autoimmun. Rev, 2005, 4, 224-229. DOI: 10.1016/j.autrev.2004.11.011

31. Rasheed, Z.; Ahmad, R.; Rasheed, N.; Ali, R. Reactive oxygen species damaged human serum albumin in patients with hepatocellular carcinoma. J. Expt. Clin. Cancer Res, 2007, 26, 515-524. 